\title{
Czasopiśmiennictwo medyczne w Wielkiej Brytanii w XIX w.
}

Słowa kluczowe: medycyna angielska, twórcy i redakcje czasopism

Ważną rolę w rozwoju myśli medycznej w Wielkiej Brytanii odgrywały czasopisma. Ich liczba, podobnie jak znaczenie, sukcesywnie wzrastały wraz z rozwojem zawodów medycznych oraz pojawiających się specjalizacji. To właśnie na łamy czasopism medycznych przeniosły się dyskusje między reprezentantami różnych specjalności, które dotąd były tematem listów wysyłanych prywatnie lub kierowanych bezpośrednio do towarzystw. Podobnie jak towarzystwa medyczne, redakcje czasopism medycznych uczestniczyły w ewolucji myśli medycznej w Wielkiej Brytanii. Środowisko medyczne tego kraju wyróżniało się pod względem dynamiki rozwoju periodyków na tle kontynentalnej Europy.

Pierwsze czasopismo medyczne - „Medical Essays and Observations" ${ }^{1}$ - zostało wydane w Szkocji w 1733 r. Fakt ten wskazuje na Szkocję jako centrum medycyny w Wielkiej Brytanii przełomu XVIII i XIX w.

Należy jednak pamiętać, że prowincjonalnego chirurga-aptekarza w XVIII w. charakteryzowała zaściankowość. Nie utożsamiali się oni z ich zawodowymi odpowiednikami, praktykującymi w Londynie, pobierającymi duże kwoty za leczenie. Pojęcie przynależności do ist-

\footnotetext{
${ }^{1}$ Czasopismo kilkakrotnie zmieniało nazwę. Od $1733 \mathrm{r}$. wydawano czasopismo o tytule „Medical Essays and Observations”. W roku 1754 r. nastąpiła zmiana nazwy na „Essays and Observations”, w 1773 r. na „Medical and Philosophical Commentaries”, w 1796 r. - „Annals of Medicine”, w 1805 r. - „Edinburgh Medical and Surgical Journal”, w 1855 r. - „Edinburgh Medical Journal”.
} 
niejących w stolicy korporacji medycznych było dla nich abstrakcją ${ }^{2}$. Postawa ta uległa zmianie wraz z początkiem XIX w. Wspomniani chirurdzy-aptekarze, tzw. praktycy ogólni, początkowo byli „półamatorskimi rzemieślnikami”, jednak nie oznaczało to braku zainteresowania rozwojem i profesjonalizacją swoich dziedzin. „Apothecaries' Act” z 1815 r. regulował zasady kształcenia adeptów wymienionych profesji medycznych, a czasopisma zawierające już w tym czasie obszerne przeglądy najnowszych pozycji książkowych stawały się dla nich źródłem wiedzy, „nowinek” pojawiających się w medycynie ${ }^{3}$. To właśnie do nich adresowanych było wiele czasopism medycznych, np. takie jak założone w 1814 r. „London Medical” oraz „Surgical and Pharmaceutcial Repository: Monthly Journal and Review”. Służyły rozpowszechnieniu nowych teorii, technik medycznych wśród praktyków na terenie całego kraju ${ }^{4}$. Nabycie periodyku medycznego mogło być również pewną oszczędnością czasu oraz środków wydawanych na bardziej kosztowne, a często trudno dostępne pozycje książkowe.

Periodyki medyczne wydawane w XIX w. w Wielkiej Brytanii różniły się: ceną (od kilku pensów np. „London Medical Repository” czy „the Lancet”, do nawet 6 szylingów - „Edinburgh Medical and Surgical Journal”), formatem (książkowy lub gazetowy, jakością papieru, ilustracji), a także częstotliwością publikowania (kwartalniki, miesięczniki, tygodniki). Kierowane były do konkretnej grupy odbiorców, zamieszczano także na ich łamach filozoficzne lub ideologiczne poglą$\mathrm{dy}^{5}$. Zawarte $\mathrm{w}$ nich treści miały wpływ na popularność. Zjawisko to miało już bowiem znamiona konkurencji.

\section{Rozwój czasopism medycznych}

Szybki wzrost popularności czasopism medycznych był częścią ogólnej, wzrastającej tendencji, charakterystycznej dla całości wydawanej od początku XIX w. w Wielkiej Brytanii prasy naukowej. Zaobserwowano wówczas ich wyraźny rozkwit, pomimo początków pierwszych periodyków już w połowie XVII w. Warto tu przypomnieć, że w roku 1665 Henry Oldenburg, sekretarz Royal Society of London,

${ }^{2}$ J. Loudon, I. Loudon, Medicine, politics and the medical periodical 1800-1850, [w:] Medical Journals and medical knowledge - historical essays, Routledge, Londyn, 1992 s. 64.

3 Tamże.

${ }^{4}$ Tamże.

${ }^{5}$ W.F. Bynum, J.C. Wilson, Periodical knowledge: medical journals and their editors in nineteenth-century Britain, [w:] Medical Journals and medical knowledge - historical essays, Londyn 1992, s. 31; J. Loudon, I. Loudon, dz.cyt., s. 59. 
założył czasopismo „Philosophical Transactions”, które było najstarszym periodykiem towarzystwa naukowego (ukazującym się do dzisiaj $^{6}$ ). Według „Waterloo Dictionary of Victorian Periodicals”, w latach 1824-1900 w Wielkiej Brytanii wydawano łącznie ok. 29 tys. naukowych czasopism i gazet (jest to liczba wszystkich publikacji bez względu na ich specjalistyczną tematykę i czas ich wydawania), z czego tylko $1 \%$, ok. 345 pozycji, wydawano komercyjnie, a $0,5 \%$ (ok. 190 pozycji) było sponsorowanych przez towarzystwa naukowe i akademie $^{7}$. Fakt, że z 535 publikacji $64 \%$ charakteryzowało się komercyjnym charakterem ${ }^{8}$, wydaje się wskazywać na szansę dodatkowego źródła dochodu jako przyczynę wydawania m.in. medycznych czasopism naukowych. Niejednokrotnie owo dążenie do szybkiego wzbogacenia się tą drogą było również powodem do szybkiego zamknięcia periodyku (często koszt druku przewyższał zysk uzyskany ze sprzedaży lub prenumeraty).

Jak podają źródła, liczba czasopism stricte medycznych w całym XIX w. oscylowała wokół 479 pozycji, ze średnią dynamiką druku na poziomie jednego czasopisma na $77 \mathrm{dni}^{9}$. W pierwszej połowie XIX w. (1800-1849) odnotowano 168 periodyków ${ }^{10}$. Na drugą połowę przypada 311 pozycji, a więc dynamika wydawania czasopism medycznych w drugiej połowie XIX w. wzrosła o blisko połowę ${ }^{11}$. Częstotliwość wydawania nowych periodyków medycznych w pierwszej połowie XIX w. oscylowała na poziomie trzech nowych pozycji na rok. Tendencja ta była dość stabilna, z wyłączeniem lat 1828-1839, kiedy to średnia liczba nowych czasopism medycznych w ujęciu rocznym osiągnęła liczbę czterech $^{12}$. Istotnym czynnikiem, który należy wziąć pod uwagę, aby uzyskać rzeczywisty stan czasopism medycznych w XIX w., jest okres

${ }^{6}$ T. Ostrowska, Polskie Czasopiśmiennictwo Lekarskie w XIX wieku (1800-1900). Zarys historyczno-bibliograficzny, Wrocław 1973, s. 11.

7 W.H. Brock, Medicine and the Victorian scientific press, [w:] Medical Journals and medical knowledge - historical essays, Londyn 1992, s. 71.

8 Tamże.

${ }^{9}$ W.F. Bynum, J.C.Wilson, dz. cyt., s. 30

${ }^{10}$ J. Loudon, I. Loudon, dz. cyt., s. 49.

${ }^{11}$ Wynikało to głównie $\mathrm{z}$ faktu, że druga połowa XIX w. obfitowała w wiele istotnych zjawisk w świecie medycyny, od dalszego kształtowania się opieki medycznej, przez profesjonalizacje zawodów medycznych i pojawienie się praktyka ogólnego, aż po nowe odkrycia, zmieniające dotychczasowe praktyki lekarskie i chirurgiczne. Czasopisma towarzyszyły wszystkim wspomnianym wcześniej zmianom społeczno-legislacyjnym, mającym miejsce $\mathrm{w}$ tamtym okresie, często biorąc bezpośredni udział w kształtowaniu nowych przepisów, definiowaniu profesji medycznych czy nawoływaniu do przeprowadzania reform.

${ }^{12}$ J. Loudon, I. Loudon, dz. cyt., s. 49. 
wydawania czasopism medycznych, który znacząco różnił się w zależności od konkretnej pozycji. Częstym zjawiskiem było wspomniane już zamykanie czasopisma $\mathrm{w}$ trakcie pierwszego roku od wydania pierwszego numeru. W latach 1825-1839 47,5\% wydawanych wtedy periodyków zostało zamkniętych, a $21,5 \%$ nie przetrwało dwóch lat ${ }^{13}$. Obraz ten uzupełniają William F. Bynum i Janice C. Wilson, którzy podają, że w 1800 r. wydawanych było 8 czasopism medycznych, a liczba ta wzrosła do $137 \mathrm{w} 1900 \mathrm{r}^{14}$ Jeśli weźmie się pod uwagę fakt, że wszystkich czasopism medycznych wydanych w XIX w. było 479, a w 1900 r. odnotowano 137, można wywnioskować, iż 342 periodyki powstały i zostały zamknięte $\mathrm{w}$ XIX stuleciu.

W okresie rozwoju czasopism medycznych w XIX w. można wyróżnić dekady wzrostu częstotliwości redagowania nowych czasopism. Okres stabilizacji, jak i spadku wydawania nowych periodyków był wyraźny. Co ciekawe, w pierwszej dekadzie XIX w. 50\% czasopism medycznych wtedy wydanych przetrwało na rynku wydawniczym okres co najmniej pięciu lat ${ }^{15}$ (przykładami są tu: wspomniany już „Edinburgh Medical and Surgical Journal” z 1805 r., drukowany przez 50 lat do roku 1855, oraz „Medico-Chirurgical Transactions”, obecny na rynku prasowym od 1809 r. aż do początków XX w., kiedy zmieniono tytuł czasopisma ${ }^{16}$. Kolejne dekady - lata 20. i 30. XIX w., cechują się w głównej mierze periodykami, które nie przetrwały 5 lat ${ }^{17}$. Wyjątkami są tu wydawany od roku 1823 ,The Lancet” (redagowany nieprzerwanie do dzisiaj), „London Medical Gazette” (od 1827 aż do 1851 r., kiedy to zmieniono nazwę na „Medical Times and Gazette” druko-

13 Tamże.

14 W.F. Bynum, J.C. Wilson, dz. cyt., s. 30.

15 Tamże, s. 33.

16 Pierwszym czasopismem medycznym w rozumieniu XIX-wiecznym, które nie zostało ujęte w podanych wyżej liczbach, były „Transactions of the Royal College of Physicians", wydawane w Londynie od roku 1768. Nie odegrało ono jednak ważnej roli, co sugeruje fakt, że w latach 1768-1820 wydano jedynie sześć tomów. W $1805 \mathrm{r}$. zaczęto wydawać „Edinburgh Medical and Surgical Journal”, wspierany przez Edynburskie Kolegium Lekarskie oraz wydawane przez Andrew Duncana juniora, profesora Instytutu Medycyny Uniwersytetu w Edynburgu. Było to pierwsze odznaczające się czasopismo medyczne, co niejako wpisuje się w dominującą rolę szkockiej myśli medycznej w Wielkiej Brytanii na początku XIX w. Czasopismo to przetrwało łącznie 50 lat i nie raz podejmowano $\mathrm{w}$ nim krytykę angielskiego odpowiednika (Królewskie Kolegium Lekarskie) za opieszałość i brak zainteresowania sprawami bieżącymi. W $1809 \mathrm{r}$. Towarzystwo Medyko-Chirurgiczne zdecydowało się wydawać „Medico-Chirurgical Transactions”, drukowane przez cały XIX oraz XX w. (analogicznie do zmiany nazwy towarzystwa w 1907 r. czasopismo rownież zmieniło nazwę na „Proceedings of the Royal Society of Medicine").

17 W.F. Bynum, J.C. Wilson, dz. cyt., s. 33. 
wany do 1885 r.) oraz „Glasgow Medical Journal”, którego pierwsza edycja pojawiła się w roku $1828 \mathrm{r}^{18}$ (wydawany do $1956 \mathrm{r}$., kiedy połączył się z „Edinburg Medical Journal” i przekształcił się w „Scottish Medical Journal"). W latach 30. XIX w. warte odnotowania są dwa periodyki, które pojawiły się w Irlandii - w 1832 r. „Dublin Medical Journal of Medical and Chemical Science” (obecnie „Irish Journal of Medical Science”) oraz w 1839 r. „Dublin Medical Press”19 (wydawany do 1865 r., kiedy zmieniono nazwę na „Medical Press and Circular" publikowany do 1961 r.) W kolejnych dwóch dekadach ponad $50 \%$ rozpoczętych periodyków przetrwało, jak już wspomniano, okres 5 lat, a 25\% było wydawanych przez 50 lat lub dłużej (w $1840 \mathrm{r}$. zaczęto wydawać „Provincal Medical and Surgial Journal”, który w 1857 r. zmienił nazwę na „British Medical Journal”, ukazuje się do dzisiaj). W latach 50. pojawiły się czasopisma poświęcone aktualnym zainteresowaniom środowiska medycznego: „tematom szaleństwa” i zdrowia psychicznego. Od 1853 r. na rynku prasowym obecny był „Asylum Journal of Mental Science”, który po dwukrotnej zmianie nazwy wydawany jest do dzisiaj pod nazwą „British Journal of Psychiatry”" ${ }^{20}$. W latach 60. XIX w. nastąpił spadek liczby nowych czasopism medycznych (źródła odnotowują druk ok. 38 czasopism, z czego ponad 20 nie przetrwała więcej niż 5 lat ${ }^{21}$ ). Nie wyjaśniono jednak przyczyn spadku dynamiki powstawania nowych periodyków w tamtym czasie. Można domniemywać, że odbywająca się wtedy konsolidacja profesji medycznych oraz reforma z $1858 \mathrm{r}$. spowodowały skupienie zainteresowania środowiska medycznego na bezpośredniej edukacji medycznej prowadzonej na terenach wiejskich, a zwłaszcza zakładanie nowych szpitali i towarzystw medycznych. Był to też okres usamodzielnienia nowych kierunków i wyłaniania się nowych specjalności medycznych (położnictwa, ginekologii, zdrowia publicznego, dermatologii). Warty odnotowania jest wydawany od 1863 r. „Annals of Military and Naval Surgery and Tropical Medicine and Hygiene”, bezpośrednio nawiązujący $\mathrm{w}$ swych treściach do zmian zachodzących w tamtym czasie $\mathrm{w}$ środowisku medycznym. Jego aktualna jak na tamte czasy tematyka nie zagwarantowała jednak periodykowi sukcesu i w konsekwencji zaprzestano jego edycji, nie doczekawszy się nawet roku od pierwszego wydania.

18 Tamże.

${ }^{19}$ H.E. Counihan, Irish Medical Journals, „Irish Journal of Medical Science” 2000, t. 169 , nr 4, s. 262.

${ }^{20}$ W.F. Bynum, J.C. Wilson, dz. cyt., s. 45.

21 Tamże, s. 34. 
Lata 70. i 80. to ponowny wzrost liczby nowych periodyków - wydrukowano w sumie ok. 120 nowych tytułów. Pomimo faktu, że nadal większość z nich zamykano jeszcze przed upływem 5 lat (ok. 57), to zaobserwować można wyraźny wzrost czasopism o okresie wydawniczym w przedziale od 6 do 50 lat (ok. 35) ${ }^{22}$. Wzrost ten był w dużej mierze spowodowany wzrastającą wtedy popularnością periodyków specjalistycznych, których treści odpowiadały na potrzeby coraz bardziej wyspecjalizowanego kierunkowo środowiska medycznego. Periodyki, tj. „Specialist”23 (wydawany w latach 1880-1881) oraz „British Journal of Dermatology" (wydawany od 1888 r. do dzisiaj), są jednym z przykładów czasopism skierowanych do konkretnych, nowych jak na tamte czasy dziedzin medycyny ${ }^{24}$. Pod koniec XIX w. nastąpił poważny wzrost liczby tytułów (pojawia się ich ok. 120), ponad połowa z nich (ok. 66) ukazywała się przez więcej niż 6 lat, a kolejne 33 pozycje mieszczą się w przedziale czasowym 50-100 lat ${ }^{25}$. Wydaje się, że przyczyną wzrostu liczby nowych periodyków był nie tylko rozwój specjalizacji, ale także regionalizacja medycyny w Wielkiej Brytanii, co w konsekwencji przyczyniło się do druku lokalnych periodyków („Sheffield Medical Journal”) oraz zakładania wielu towarzystw medycznych na terenie całego kraju („Transactions of the North of England Obstetrical and Gynaecological Society").

Podsumowując, w XX w. można odnotować aż 12 periodyków założonych jeszcze w pierwszej połowie XIX w. Są to: „Edinburgh Medical Journal”, „Journal of the Royal Society of Medicine”, „Glasgow Medical Journal”, „The Lancet”, „Transactions of the Hunterian Society”, „Dublin Journal of Medical Science”, „Guy's Hospital Reports”, „St. Thomas' s Hospital Reports”, „British Medical Journal”, „Pharmaceutical Journal and Transactions”, „Retrospect of Medicine” oraz „Transactions of the Pathological Society of London”26.

Wydawane czasopisma medyczne można też analizować przez pryzmat adresatów. Za podziałem W.F Bynuma i Janice Wilson można wyróżnić następujące typy czasopism: ogólnomedyczne (kierowane do całej społeczności medycznej), specjalistyczne (kierowane do zawężonej grupy praktyków medycznych), naukowe (poruszające

\footnotetext{
${ }^{22}$ Tamże.

${ }^{23}$ Czasopismo poświęcone było następującym, wyłaniającym się specjalizacjom: oftalmologia, otologia, rynolaryngologia, odontologia, dermatologia, psychiatria (nazywana również psychologią) oraz ginekologia.

${ }^{24}$ W.F. Bynum, J.C. Wilson, dz. cyt., s. 45.

${ }^{25}$ Tamże, s. 34.

${ }^{26}$ J. Loudon, I. Loudon, dz. cyt., s. 53.
} 
kwestię związane z bakteriologią, mikroskopią, anatomią i fizjologią), popularno-prozdrowotne (kierowane do ogółu społeczeństwa) oraz medycyny niekonwencjonalnej (zajmujące się medycyną alternatywną - homeopatią, hydropatią czy frenologią) ${ }^{27}$.

W pierwszej połowie XIX w. (do roku 1840) najczęściej publikowane były periodyki kierowane do całego środowiska medycznego (prawdopodobnie $\mathrm{w}$ związku z brakiem wyraźnego jeszcze podziału między poszczególnymi profesjami medycznymi oraz z rosnącą liczbą lekarzy/chirurgów i aptekarzy, co stwarzało większą grupę potencjalnych odbiorców, a więc i większą szansę na potencjalny zysk). Popularność ich spadła na rzecz periodyków specjalistycznych, których rozkwit można zaobserwować od 1870 r., aby pod koniec XIX w. osiągnąc liczbę ponad 50 nowych tytułów.

Kolejną grupę tworzą czasopisma kierowane do ogółu społeczeństwa. Pisma te, poświęcone medycynie niekonwencjonalnej, osiągnęły szczyt publikowania w latach 40 . XIX w., kiedy to odnotowano liczbe 20 nowych tytułów na dekadę, co plasowało je na równi z periodykami przeznaczonymi dla całej społeczności medycznej. Częstotliwość wydawnicza czasopism o tej tematyce spada jednak pod koniec wieku XIX, zatrzymując się na poziomie 10 nowych tytułów na dekadę.

Najmniejszą częstotliwością przez cały XIX w. charakteryzowały się czasopisma naukowe, nie przekraczając liczby 5 nowych tytułów na dekadę. Słaba dynamika wydawania nowych periodyków naukowych wydaje się zaskakująca, gdyż XIX w. obfitował w liczne odkrycia i wynalazki, stanowiąc tym samym źródło tematów dla nowych redakcji czasopism. Jednakże brak medycyny laboratoryjnej oraz fakt, że to czasopisma ogólnomedyczne zwięźle opisywały tematy związane z odkryciami naukowymi, rozszerzając je o dyskusje między członkami profesji medycznych, czego brakowało czasopismom naukowym, mogło być powodem niskiego zainteresowania drukiem nowych periodyków w tym temacie. Co więcej, za sprawą wprowadzonych reform regulujących zdobycie uprawnień do wykonywania zawodu liczba członków środowiska medycznego rosła, a więc pojawiała się coraz większa grupa odbiorców treści ogólnomedycznych. Gdy analizuje się okres publikowania poszczególnych czasopism medycznych, można stwierdzić, że dominacja medycznych typów czasopism (ogólnomedycznych i specjalistycznych) wynikała również z większej szansy na ich powodzenie - duża część czasopism w tych grupach była redagowana dłużej niż 6 lat, nierzadko przekraczając 50 lat. Dla kontrastu

${ }^{27}$ W.F. Bynum, J.C. Wilson, dz. cyt., s. 32. 
należy zaznaczyć że, tylko 5 czasopism medycznych z grupy naukowych i popularno-prozdrowotnych wydawanych w XIX w. było publikowanych przez 50 lat lub dłużej ${ }^{28}$.

Kolejnym istotnym aspektem rozwoju czasopism medycznych było miejsce ich wydawania. Podobnie jak w przypadku towarzystw medycznych, dominującą rolę pod względem wydawania czasopism medycznych w Wielkiej Brytanii w XIX w. pełnił Londyn. To w Londynie mieszkało $10 \%$ populacji Królestwa, i to tam przebywało na stałe ok. 15\% wszystkich lekarzy ${ }^{29}$. Zmiany w sposobie kształcenia studentów zawodów medycznych również sprzyjały stolicy - 50\% wszystkich absolwentów uczelni medycznych z Królestwa przybywało do Londynu celem odbycia praktyki ${ }^{30}$. Miało to wymierny wpływ na miejsce redagowania większości czasopism medycznych - 75\%, 364 z 497 było publikowanych właśnie $\mathrm{w}$ stolicy ${ }^{31}$, co bezpośrednio wpływało na ich dostępność dla miejscowych czytelników. Pozostałe dwa ośrodki wydawnicze w Wielkiej Brytanii to Edynburg oraz Dublin. Stolica Szkocji, głównie dzięki wybitnej generacji profesorów i studentów z końca XVIII oraz początku XIX w., dominowała w medycynie do lat 20. XIX w., kiedy straciła pozycję lidera na rzecz stolicy Anglii. Trzecim w kolejności był Dublin z 9 czasopismami medycznymi wydawanymi od początku XIX w., do dwóch publikowanych w wieku XX ${ }^{32}$. Sukces $\mathrm{w}$ tej mierze stolicy Irlandii wynikał z dużej populacji tego kraju (ponad 50\% całego Królestwa Wielkiej Brytanii) oraz z dobrze zorganizowanej tam opieki szpitalnej. Panująca bieda zwiększyła zapotrzebowanie na opiekę szpitalną, co paradoksalnie również zwiększało szansę na obserwację kliniczną różnych przypadków chorobowych ${ }^{33}$. Ponadto

28 Tamże, s. 34.

${ }^{29}$ J. Loudon, I. Loudon, dz. cyt., s. 34.

30 Tamże.

${ }^{31}$ Tamże.

${ }^{32}$ Lista Irlandzkich czasopism medycznych wydawanych w XIX oraz XX w.: „The Dublin Medical and Physical Essays Quarterly” 1807-1808 (6 tomów), „The Transactions of the Association of the Fellows and Licentiates of the King and Queens College of Physicians” (,Dublin Medical Transaction”) 1817-1830 (6 tomów), „The Dublin Hospital Reports” 1817-1830 (6 tomów), „The Dublin Philosophical Journal and Scientific Review” 1825-1827 (6 tomów), „The Dublin Journal of Medical and Chemical Science” (teraz: „The Irish Journal of Medical Science”) 1832-do teraz, „Dublin Medical Press” („Medical Press Circular”) 1839-1961, „Dublin Hospital Gazette” („Dublin Hospital Gazette and Journal of Practical Pharmacy”) 1845-1962, „Irish Hospital Gazette” 1873-1875, „Journal of Irish Medical Association” 1867-1871, „Journal of Irish Medical Association” 1901-1914, „Ulster Medical Journal” 1937-do teraz. H.E. Counihan, Irish Medical..., dz. cyt., s. 262.

33 Tamże, s. 266. 
duża śmiertelność dostarczała ciał do sekcji zwłok ${ }^{34}$, co z kolei stawało się inspiracją do podejmowania różnych problemów badawczych opisywanych w tamtejszych czasopismach (z których 3 z 9 były oparte na raportach szpitalnych). Tą drogą dzielono się także swoimi obserwacjami medycznymi.

\section{Cel wydawania czasopism medycznych}

Założenie nowego czasopisma medycznego wiązało się z różnorodnością celów, którym miało ono służyć. Celem nadrzędnym było propagowanie myśli medycznej, głównie wśród przedstawicieli zawodów medycznych, członków towarzystw medycznych, co miało przyczynić się do ich edukacji. Pełniło również rolę informacyjną o bieżących wydarzeniach $^{35}$ (istniały czasopisma skierowane do osób spoza środowiska medycznego, jednak, jak już wspomniano, w większości nie cechowały się one długą obecnością na rynku wydawniczym ${ }^{36}$ ). W pismach prezentowano m.in. przypadki kazuistyczne, przeprowadzano dyskusje, a wątpliwości drukowano w formie listów lub komunikatów. Sporo też miejsca poświęcano na omówienia oraz recenzje książek oraz innych periodyków. Dodać warto, że 50\% wszystkich recenzji oraz przeglądów literatury dotyczyło publikacji wydawanych za granica $\left.{ }^{37}\right)^{38}$. Publikowano też wywiady medyczne, wiadomości z towarzystw medycznych, wykłady, głównie jednak wygłaszane w Londynie lub Edynburgu. Ponadto umieszczano nekrologii oraz informacje dotyczące meteorologii, topografii miast oraz zasad podróży ${ }^{39}$.

Dość często czasopisma były powiązane $\mathrm{z}$ istniejącym towarzystwem medycznym (np. Towarzystwo Medyko-Chirurgiczne z czasopismem „Medico-Chirurgical Transactions”) i stawały się forum do publikowania artykułów i sprawozdań z działalności towarzystwa. Co więcej, zachodzące zmiany legislacyjne, kształtujące zarówno społeczeństwo, jak i środowisko medyczne („New Poor Law”, „Medical Act”), również sprzyjały i stanowiły dodatkową motywację do zakładania czasopism medycznych. Służyły one wtedy do zaprezentowania własnych opinii czy nawet stawały się pewnym wyrazem sprzeciwu

\footnotetext{
${ }^{34}$ Tamże.

${ }^{35}$ J. Loudon, I. Loudon, dz. cyt., s. 56.

${ }^{36}$ W.F. Bynum, J.C. Wilson, dz. cyt., s. 34.

${ }^{37}$ Pojęcie praw autorskich nie istniało w XIX w., a więc powszechną praktyką było publikowanie przedruków z Europy kontynentalnej. Nie było to jednak odbierane jako plagiat, a raczej jako uznanie dla autora, którego artykuł zdobył popularność.

${ }^{38}$ J. Loudon, I. Loudon, dz. cyt., s. 56.

39 Tamże.
} 
do postępujących zmian (jak np. „The Lancet”). W konsekwencji nowy periodyk prowokował, a nawet wymuszał stworzenie nowego czasopisma, które prezentowałoby odmienne stanowisko (kontrczasopismem dla „The Lancet” była „London Medical Gazzette”).

Periodyki medyczne były też środkiem wyrażania wspólnoty interesów, jedności poszczególnej grupy przedstawicieli zawodów medycznych, tak jak „Provincial Medical and Surgical Journal”, późniejszy „British Medical Journal”. Zespół redakcyjny wspomnianego pisma utożsamiał się z lekarzami praktykującymi poza Londynem oraz z praktykami ogólnymi (general practitioners). Jak już wspomniano, liczne czasopisma, ukazujące się głównie w drugiej połowie XIX w. oraz na początku XX w., kierowane były do przedstawicieli powstałych specjalizacji medycznych, takich jak: okulistyka $\left(7^{40}\right)$, dentystyka (13), zdrowie publiczne (19), położnictwo i ginekologia (9), gruźlica (2), laryngologia (3), ortopedia (1), radiologia (1), anestezjologia (1), pediatria (1), dermatologia (5), medycyna tropikalna (5) i medycyna wojskowa (5) ${ }^{41}$.

Wśród pozostałych celów, które niejednokrotnie stawały się ważniejsze od wymienionych wyżej, wspomnieć należy dążenie do wyrażenia krytyki $w$ stosunku do prestiżowych londyńskich środowisk („The Lancet”), a także walka z powszechnym zjawiskiem znachorstwa. Jak podaje K. Codell Carter, w 1810 r. stosunek liczby znachorów do wykwalifikowanych lekarzy wynosił 9:1. Zjawisko to bowiem było znacznie bardziej rozpowszechnione w Wielkiej Brytanii niż w jakimkolwiek innym kraju Europy kontynentalnej. Temat ten bardzo często poruszano na łamach czasopism medycznych: publikowano artykuły, dyskusje, listy lekarzy, czasem nawet znachorów ${ }^{42}$. Definiowano ich jako tych, którzy używają ,,sekretnych składników” (niewymienionych w farmakopeach, co nie oznaczało zawsze, że były one nieskuteczne) oraz reklamują udane leczenie lub nad wyraz skuteczne specyfiki ${ }^{43}$. Aby uzyskać pełen obraz zjawiska uprawiania medycyny przez niewykwalifikowanych praktyków, należy uwzględnić trzy czynniki:

1) znachorstwo nie było uważane za tak poważny problem przez społeczeństwo, w odróżnieniu od opinii środowiska medycznego,

40 Cyfra w nawiasie oznacza liczbę czasopism, które ukazały się w danej tematyce w latach 1830-1899.

41 B. Urbanek, Kształtowanie się specjalności lekarskich na ziemiach polskich w latach 1860-1914, Warszawa 2010, s. 33.

${ }^{42} \mathrm{~K}$. Codell Carter Ph.D, The concept of quackery in early nineteenth century British medical periodicals, „Journal of Medical Humanities” 1993, t. 14, nr 2, s. 89.

43 Tamże, s. 91. 
2) znachorzy często uzyskiwali aprobatę wykwalifikowanych lekarzy dla swoich praktyk oraz używanych specyfików. Bez tego zjawisko nie byłoby tak powszechne,

3) niewielu wykwalifikowanym praktykom medycznym udawało się osiągnąc finansowy sukces, co $\mathrm{w}$ konsekwencji zmuszało ich do zdobywania dodatkowych środków poza swoimi praktykami, często właśnie trudniąc się znachorstwem ${ }^{44}$.

Szczególnie redakcja „The Lancet” Thomasa Wakleya mocno angażowała się w walkę ze znachorstwem, jako że zdawano sobie sprawę, iż trudnią się tym zajęciem również przedstawiciele różnych prominentnych społeczności oraz towarzystw. Przykładem jest tu opublikowany w 1840 r. na łamach „The Lancet” anonimowy list od członka Królewskiego Kolegium Chirurgicznego oraz Towarzystwa Aptekarzy, oficjalnie przyznającego się do zajmowania się znachorstwem ${ }^{45}$. Praktyka sprzedawania przez licencjonowanych lekarzy certyfikatów potwierdzających autentyczność leków używanych przez znachorów nieraz kończyła się oskarżeniem lekarza na łamach „The Lancet”, $\mathrm{w}$ konsekwencji doprowadzając do pozbawienia danej osoby członkostwa jednego z londyńskich towarzystw. Thomas Wakley sprzeciwiał się zdobywaniu dodatkowych środków przez wykwalifikowanych lekarzy poza ich praktykami profesjonalnymi. Rozpowszechniał on pogląd, że brak jawności zarówno w przypadku składników leków, jak i w samej technice przekazywania wiedzy o jego działaniu jest naganne. Wakley sprzeciwiał się nawet używaniu łaciny oraz terminologii technicznej, twierdząc, że „zakrywały” one wiedzę o istocie leku, czyniąc ją w pewnym sensie tajemną. Posługiwanie się tym nazewnictwem, według Wakleya, mogło być podstawą do formułowania oskarżeń o uprawianie znachorstwa ${ }^{46}$. W ten sposób, idąc tym tropem rozumowania, oskarżonych zostało wielu lekarzy, praktyków ogólnych oraz aptekarzy, a nawet towarzystw medycznych ${ }^{47}$.

\section{Właściciele i redaktorzy czasopism medycznych}

Wraz z coraz większą liczbą czasopism medycznych zainteresowanie zaczęły wzbudzać osoby, które były pomysłodawcami nowych periodyków. Stanowisko redaktora nie było jeszcze w środowisku

${ }^{44}$ Tamże, s. 92.

45 Tamże, s. 91.

${ }^{46}$ Tamże.

${ }^{47}$ Towarzystwo Medyko-Chirurgiczne zostało oskarżone przez Wakleya o promowanie znachorstwa, kiedy spotkania członków zostały zamknięte dla reporterów „The Lancet”. 
medycznym dobrze określone na początku XIX w., a więc można postawić tezę, że ta droga kariery została zdefiniowana właśnie w XIX stuleciu. Istotnym elementem rozważań o czasopismach medycznych jest kwestia ich właścicieli.

W XIX w. możliwy jest podział na trzy typy czasopism, uwzględniający problem własności. I tak:

1) właściciel prywatny, który nie był redaktorem czasopisma (dobrym przykładem wydaje się Richard Phillips, właściciel „Medical and Physicial Journal" wydawanego od 1799 do 1802 r., który nie pełnił funkcji redaktora, jednak miał realny wpływ na publikowane treści),

2) właściciel czasopisma był równocześnie jego redaktorem. Można tu wymienić: wspomnianego już Thomasa Wakleya ze swoim „The Lancet”, Petera Hennisa Greena i jego „Provincial Medical and Surgical Journal” (późniejszy „British Medical Journal”) oraz „London Medical Repository” prowadzone przez właściciela George'a Mana Burrowsa,

3) czasopismo wydawane przez organizacje lub instytucje (towarzystwa medyczne, szpitale oraz uniwersytety), będące platformą do drukowania głównie sprawozdań, raportów lub wiadomości z działalności tychże instytucji ${ }^{48}$.

Funkcja redaktora periodyku medycznego była najczęściej jednym z wielu stanowisk, które zajmowała dana osoba. Mnogość zajęć przedstawicieli zawodów medycznych była cechą charakterystyczną dla epoki wiktoriańskiej, a powodem tego był czynnik finansowy oraz ambicja. Najbardziej prestiżową pozycją w ówczesnej hierarchii stanowisk dla lekarzy były konsultacje prywatne, a miarą sukcesu - praktyka kliniczna, stanowiąca podstawę do rozwoju kariery zawodowej. Pozostali, którzy z różnych względów nie mogli odnieść sukcesu tylko $\mathrm{w}$ oparciu o prywatną praktykę, starali się o stanowisko $\mathrm{w}$ - szeroko pojętej - państwowej opiece zdrowotnej. Praca w szpitalach, inspektora rządowego („,Poor Law Officer”), lekarza więziennego lub lekarza w przytułku dawała niewielki, jednak stabilny zarobek. Praca jako redaktor periodyku medycznego była jednym z dodatkowych zajęć, które stanowiło uzupełniające źródło dochodu ${ }^{49}$.

${ }^{48}$ J. Loudon, I. Loudon, dz. cyt., s. 54; P. Bartrip, The British Medical Journal: a retrospect w Medical Journals and medical knowledge - historical essays, Londyn 1992, s. 126.

${ }^{49}$ Zdarzały się sytuacje, w których redaktorzy traktowali swoje czasopisma jako miejsce do zareklamowania swoich usług. Przykładem jest George Shipman, który w swoim czasopiśmie „The Doctor”, skierowanym do ogółu społeczeństwa, wydawa- 
Krzywdzące byłoby jednak stwierdzenie, że bodźcami, które skłaniały przedstawicieli profesji medycznych do objęcia stanowiska redaktora lub do wydawania własnego czasopisma, był czynnik ekonomiczny lub chęć reklamy. Gdy przeanalizuje się życiorysy prominentnych postaci w brytyjskiej medycynie w XIX w., można stwierdzić, że większość $\mathrm{z}$ nich znajdowała zatrudnienie (z reguły w początkowych latach pracy) w zespole redakcyjnym lub trudniła się rolą korespondenta albo nawet pełniła obowiązki redaktora czasopisma czy właściciela czasopisma medycznego. Wspomniani już Thomas Wakley (założył „The Lancet” w wieku 28 lat), Peter Hennis Green ${ }^{50}$ (korespondent „The Lancet” w Dublinie), George Man Burrows („London Medical Repository”) oraz Alfred Swain Taylor (redagował „Medical Gazette”) czy Thomas Spencer Wells (redaktor „Medical Times and Gazette”) są tego potwierdzeniem. Co więcej, każda z wymienionych osób (oprócz Greena) była członkiem jednego $\mathrm{z}$ istniejących wtedy towarzystw medycznych: Wakley - członek Królewskiego Kolegium Chirurgicznego w Londynie, Burrows - Towarzystwa Medyko-Chirurgicznego w Londynie, Wells - Królewskiego Kolegium Chirurgicznego w Londynie, Taylor - Królewskiego Kolegium Lekarskiego w Londynie. Duża aktywność zawodowa przedstawicieli profesji medycznych kwalifikuje ich jako ludzi ambitnych i zdeterminowanych do osiągnięcia sukcesu w swoich dziedzinach. Objęcie stanowiska redaktora lub założenie czasopisma medycznego było dla ówczesnego środowiska medycznego (szczególnie, jak wspomniano, dla ludzi w młodym wieku od 25 do 40 lat) środkiem do osiągnięcia prestiżu i sukcesu, a nie zwieńczeniem kariery. Był to zaledwie kolejny z etapów przyczyniający się do zdobycia bądź ugruntowania lepszej pozycji zawodowej ${ }^{51}$. Świadczyć o tym może ogólna tendencja do stosunkowo krótkiego czasu pełnienia funkcji redaktora, zwykle nieprzekraczającego $10 \mathrm{lat}^{52}$, a najczęściej mieszczącego się $\mathrm{w}$ przedziale od 2 do 7 lat. Stanowisko redaktora ewoluowało i z czasem (pod koniec XIX w.) oferowa-

nym w latach 1833-1837, reklamował swoje specyfiki lecznicze i przypominał swoim czytelnikom o możliwości konsultacji lekarskiej „w każdy poniedziałek, środę i piątek od 17.00 do 20.00 przy ulicy Broadway 4 Ludgate Hill. Koszt wizyty wynosi 2 szylingi i 6 pensów". Jednakże nie była to postawa dominująca.

${ }_{50}$ Peter Hennis Green (1803-1870) - irlandzki lekarz, w wieku 21 lat pracował dla „The Lancet” jako korespondent z Dublina i w dużej mierze odpowiada za sukces czasopisma Wakleya w latach 20. i 30. XIX w. W wieku 37 lat popadł w konflikt z Thomasem Wakleyem i założył „The Provincial Medical and Surgical Journal”, który 17 lat później zmienia nazwę na „British Medical Journal”.

${ }^{51}$ W.F. Bynum, J.C. Wilson, dz. cyt., s. 42.

52 Tamże. 
no lepsze perspektywy zawodowe, jak i finansowe, a samo podejście do zakładania czasopism zmieniło się z indywidualnego (z początku XIX w.) do bardziej kolektywnego (koniec XIX stulecia) ${ }^{53}$.

Poza aktywnością związaną z samym redagowaniem czasopisma redaktorzy decydowali również o formacie, częstotliwości i kosztach wydawania. Nadawali oni charakter publikowanym tekstom oraz kierunek, w którym zdecydowali się podążać, nierzadko wchodząc $\mathrm{w}$ konflikty z innymi redaktorami lub nawet całymi społecznościami medycznymi. O niepowodzeniu danego periodyku mogło decydować wiele czynników, od słabej jakości tekstów, przez monotonną zawartość, aż po brak umiejętności redaktora do zarządzania finansami i kontrolowania relacji kosztów do zysków ${ }^{54}$. Elementem, który może wskazywać na problemy czasopisma, była zmiana nazwy (która z reguły oznaczała zmianę redaktora) lub fuzja $\mathrm{z}$ innym czasopismem (zwykle oznaczająca problemy finansowe) ${ }^{55}$.

Przyczyną niepowodzenia mogła być też konkurencja, która panowała na początkującym rynku wydawniczym. Przykładem czasopisma, które odniosło sukces od początku swojego istnienia, przewyższając sprzedaż większości istniejących wtedy czasopism, a tym samym przyczyniając się do zamknięcia wielu innych czasopism, był „The Lancet” Thomasa Wakleya. Czasopismo to od początku odznaczało się dużą popularnością, pomimo faktu, iż - jak podają niektóre źródła - Wakley traktował swoje czasopismo jako narzędzie w drodze na stanowisko koronera w Middlesex oraz miejsce w parlamencie (wydaje się, że zainteresowanie Wakleya czasopismem rosło w miarę wzrostu popularności oraz skuteczności drukowanego przez niego periodyku). Wydawane jako tygodnik czasopismo mogło dobrze reagować na bieżące wydarzenia, drukując związaną z nimi korespondencję oraz polityczne komentarze ${ }^{56}$. Atutami tymi nie mogły się pochwalić dominujące wtedy miesięczniki czy kwartalniki ${ }^{57}$. Dodatkowo „The Lancet” wyróżniał się niewybrednym językiem publikowanych treści oraz - jak już wspomniano - wyraźną opozycją do społeczności lekarskiej (w szczególności do Kolegiów Lekarskiego i Chirurgicznego). Dosadnie wyrażane opinie na łamach czasopisma przyczyniły się jednak też do kolektywnej niechęci w stosunku do Wakleya i jego periodyku. Redaktorzy wydawanych wówczas innych periodyków,

\footnotetext{
${ }^{53}$ Tamże, s. 43.

${ }^{54}$ J. Loudon, I. Loudon, dz. cyt., s. 54.

55 W.F. Bynum, J.C. Wilson, dz. cyt., s. 39.

${ }_{56}$ Tamże, s. 38.

57 Tamże, s. 39.
} 
w obawie o utratę czytelników, decydowali się publikować „lekkie” treści w niezbyt obszernej zawartości, co miało usatysfakcjonować zajętego pracą lekarza, zapewnić mu pewną rozrywkę $e^{58}$. Przykładem w tym względzie jest „London Medical Circular”, którego redaktor w $1852 \mathrm{r}$. (w pierwszym sygnalnym numerze) stwierdził, że periodyk stworzy przyjemną i użyteczną możliwość do czytania przez pół godziny ${ }^{59}$. Jednak też bardzo często publikowano w czasopismach suche fakty lub sprawozdania, prezentując przy okazji wyniosły styl, jak np. w „Edinburgh Medical and Surgical Journal”, w ówczesnym odczuciu reprezentując poukładany i dżentelmeński charakter twórców ${ }^{60}$. Język w „The Lancet”, jak wspomniano, już był nieformalny, często wręcz złośliwy, nierzadko wyrażający personalne ataki na organizacje medyczne i ich członków, co w konsekwencji oznaczało, że publikowane treści stawały się często przyczyną sporów. Co więcej, Wakley, chcąc przedstawiać szeroki ogląd na sytuację praktyków medycznych, zatrudniał korespondentów w innych częściach Królestwa (np. Petera Hennisa Greena w Dublinie), którzy również wpisywali się w krytyczny ton, wyrażając swój sprzeciw, a nawet wyśmiewając krajowe Kolegia Lekarskie i Chirurgiczne ${ }^{61}$. Krytycy zarzucali Wakleyowi przedrukowywanie przemówień wygłaszanych przez renomowanych chirurgów niejednokrotnie bez ich zgody oraz skupianie się na wydarzeniach mających znamiona skandali ${ }^{2}$. Podejście Wakleya do wydawania czasopism było ryzykowne, jednak wydaję się, że charakter „The Lancet” dobrze wpisywał się w atmosferę niezadowolenia, jaka panowała w środowisku medycznym w połowie XIX w., a nieraz krytyczne treści korespondowały z opiniami praktyków medycznych oraz studentów.

Niechęć przedstawicieli środowiska lekarskiego i chirurgicznego, zrzeszonych głównie w swoich Kolegiach w Londynie, do „The Lancet" oraz do Wakleya doprowadziły do wydawania przez sprzyjających im redaktorów nowych, konkurencyjnych czasopism przyjmujących formę tygodnika, takich jak „London Medical Gazette” z 1827 r., które miały przejąć czytelników „The Lancet” oraz stanowić alter-

${ }^{58} \mathrm{~S}$. Frampton, Why are medical journals so dull? A Potted history of tedium in medical journals, https://conscicom.org/author/sallycatherineframpton [dostęp: 31.08.2017].

59 Tamże.

${ }^{60}$ J. Loudon, I. Loudon, Medicine, politics..., dz. cyt., s. 60.

${ }^{61}$ Peter Hennis Green pod pseudonimem „Erinensis” publikował w „The Lancet” krytyczne treści o Irlandzkim środowisku medycznym i wpisywał się tym samym w krytyczny, a nawet prześmiewczy styl pisania tekstów o angielskich przedstawicielach zawodów medycznych Thomasa Wakleya.

${ }^{62}$ S. Frampton, dz. cyt. 
natywę dla treści publikowanych przez Wakleya ${ }^{63}$. Zabraniano zarazem cytowania lub przedrukowywania treści z „The Lancet”, celem jego całkowitej marginalizacji. Przez następne dwie dekady od opublikowania „The Lancet” pojawiło się ponad 12 tygodników mających konkurować z periodykiem Wakleya, jednak żaden nie odniósł tak spektakularnego sukcesu ${ }^{64}$. Pomimo krytyki, jaka spadała na Wakleya oraz jego czasopismo, należy zauważyć, że „The Lancet” odznaczał się również publikowaniem treści wysokiej jakości w tematach medycznych w ujęciu społecznym i legislacyjnym, starannie wydanych ${ }^{65}$.

\section{Summary \\ The history of the medical print media in Great Britain in XIX century}

The text presents the rapid development of medical periodicals in Great Britain in XIX century as well as their prominent founders. The new phenomenon of medical periodicals started simultaneously with the development of medicine and was especially visible in Great Britain where it clearly distinguished itself by the number and frequency of journals when compared to other European countries at that time.

${ }^{63}$ W.F. Bynum, J.C. Wilson, dz. cyt., s. 37.

${ }^{64}$ Tamże.

65 J. Loudon, I. Loudon, Medicine, politics..., dz. cyt., s. 62. 